\title{
China in French Tourist Industry Discourse: From Orientalist Imaginary to Chinese Postmodernity
}

Florent VILLARD

\section{(2) OpenEdition}

\section{Journals}

\section{Electronic version}

URL: http://journals.openedition.org/transtexts/193

DOI: $10.4000 /$ transtexts. 193

ISSN: 2105-2549

\section{Publisher}

Gregory B. Lee

\section{Printed version}

Date of publication: 1 May 2006

Number of pages: 138-153

ISSN: 1771-2084

\section{Electronic reference}

Florent VILLARD, « China in French Tourist Industry Discourse: From Orientalist Imaginary to Chinese Postmodernity 》, Transtext(e)s Transcultures 跨文本跨文化 [Online], 1 | 2006, Online since 13

September 2009, connection on 01 May 2019. URL : http://journals.openedition.org/transtexts/193 ; DOI : 10.4000/transtexts.193 


\title{
China in French Tourist Industry Discourse : From Orientalist Imaginary to Chinese Postmodernity BY Florent Villard
}

\begin{abstract}
This article discusses the contradictory representations of an imaginary China as invented by the French tourist industry discourse : on the one hand the traditional Orientalist representation of a mythic, reified and timeless China, and on the other hand, the increasingly obvious assessment of China as modern and contemporary. The fact that the tourist industry evokes a contemporary, ambitious and active China, tends, however, to deconstruct the Orientalist imaginary of a timeless China which they themselves describe. Tourist industry discourse negotiates this contradiction by insisting on a post-modern dimension. As they adapt their products to new Chinese realities, the travel agents present an "Oriental post-modernity" - a world where an eternal, both contemporary and a-historic, present prevails - instead of a "lost Orient". They sell the utopian dream of a harmonious world, a seamless modernity which would not have "melted into air" local cultures and traditional practices.
\end{abstract}

Cette étude discute des représentations contradictoires de la Chine imaginaire telle qu'elle est inventée par le discours touristique français : la représentation orientaliste traditionnelle d'une Chine mythique réifiée et intemporelle d'un côté, et la prise en compte, de plus en plus flagrante, non seulement d'une Chine moderne mais aussi contemporaine de l'autre. L'évocation récurrente par le discours touristique d'une Chine au présent, ambitieuse et agissante, n'est-elle cependant pas susceptible de déconstruire l'imaginaire orientaliste d'une Chine a-historique telle que la présentent les voyagistes ? Nous postulons que le discours touristique négocie cette contradiction par l'insistance qu'il met à donner une dimension postmoderne à la Chine. Adaptant leurs produits aux nouvelles réalités chinoises, les voyagistes substituent un "Orient postmoderne" à l'ancienne représentation d'un "Orientpassé": la condition chinoise serait celle d'une "postmodernité orientale", un monde de l'éternel présent, sans histoire mais contemporain. Ils vendent à leur clients l'utopie d'un monde apaisé, une modernité sans rupture qui n'aurait pas bouleversé les pratiques et cultures locales traditionnelles.

这篇论文讨论了由法国的旅游话语所杜撰的有关于一个想象的中国的矛盾表 述：一方面是有关于一个神秘、具体可感而永恒存在的中国的传统东方主义式 的表述; 而另一方面是越来越多而明显的关于一个现代且当代的中国的估价。 
旅游工业唤起了一个当代的、雄心勃勃且积极的中国, 这一事实却趋向于解构 旅游中介所描述的对永恒存在的中国之东方主义式的想象。旅游话语通过坚持 一种后现代主义的维度来处理这种矛盾。当他们调整自己的“产品”以适应新 的中国现实的时候,那些旅游机构呈现了一种“东方的后现代性”- - 一个拘 于当代而又超越历史的世界, 在这一世界里占优势的是永恒的现时一一而非一 个 “逝去的东方”。他们贩卖的是关于一种和谐的世界、没有断裂的现代性的 乌托邦的梦想，其中的现代性将不会使当地的文化与传统的实践“烟消云散”。

Les écrivains tentés de comparer les Chinois aux Anglo-saxons en sentiront bien vite la difficulté, Ils ne tarderont pas à reconnaître que certaines particularités, prises d'abord pour des caractéristiques des Chinois, sont simplement des traits communs à tous les Orientaux. (Arthur H. Smith) 1

Whenever a tourist longing for "chineseness" reads through a tourist brochure or enters a travel agency, whether it be Asia, Kuoni, La Maison de la Chine or any other French tourist operator, he is presented with various products so as to satisfy his hunger for exoticism, all bearing attractive titles: "Lumières impériales" (Imperial lights), "Lumières de Chine" ( Lights of China), "Chine du Sud authentique" (Authentic Southern China), "Chine classique des Han" (Classical Han China), "L'Empire céleste" (The Empire of Heaven). The tourist can also find more specific titles, such as: "Les montagnes jaunes" (The Yellow Mountains), "Aux sources du Tai Chi" (The Roots of Tai Chi), "Confucius et le Pic de l'Est" (Confucius and the Eastern Peak), "Les rencontres de Chengde" (Encountering Chengde), or even "Chine rouge" (Red China) or "L'Empire du dragon" (The Empire of the Dragon). Although it can take various forms, China, as a product, is sold without ever overstepping the flare paths which are enclosed in the tourist industry imaginary. Considered as an image, it cannot be distinguished from the representations of "Asia" and the "Orient", which, as geographical entities, and now as discursive identities too, are often interlaced in tourism discourse. Such a confusion reveals the fact that within the popular imaginary concerning the Orient and Asia, the internal differences among these cultural identities which are nothing but intellectual productions can most of the time scarcely be made out. It also reminds us that the orientalist discourse, as Edward Said identified it, cannot be monolithic in today's globalised and postmodern world, and that there is an infinite number of imaginary Orients in the field of popular culture. $\underline{2}$

1 Arthur H. Smith, Mceurs curieuses des Chinois, Paris, Payot, 1927, p. 11. 2 Edward W. Said, Orientalism, NewYork, Vintage Books, 1979. "The connective tissue of Orientalism is not its conscious monolithic inflexibility [...] Orientalism cannot be appreciated only as academic discourse ; it is a cultural discourse in the widest possible sense, it is simply what is known and taken for granted. At the level of popular culture, Orientalism is most ubiquitous and most potent.", in Ziauddin Sardar, Orientalism: Concepts in the Social Sciences, Buckingham, Open University Press, 1999, p. 114. Nowadays, the theoritical issues of Orientalism cannot be reduced to a simple opposition between a subject "Occident" which created its own object, the "Orient". The orientalist discourse is not only present in the "texts" of the "Occident" - geographically and culturally speaking - anymore. In China, a phenomenon of autoorientalisation has emerged: the imaginaries of Orientalism are being exploited and mobilized so as to reinforce cultural and national identity. If the "Orient" is an imaginary world which is represented, the "Occident" can only be seen as the enonciating subject which represents it. The "Orient" is the projection of the Other of the "Occident". Hence a paradoxal situation: China itself must be located in the position of the "Occident" to find for itself oriental characteristics. The particular situation of Japanese Orientalism also contributes to the deconstruction of the strict dichotomy between "Orient" and "Occident" as elaborated by Said. Koichi Iwabuchi deals with the nostalgia in the 
What is then to be found in touristic booklets ? It is relevant to analyse this, from both semiologic and historical points of view, the words, sentences, photographs, colours, place names, monuments and references to cultural habits which have been chosen by their writers. To understand better and render coherent of the recurring images and discourses which appear in various booklets, one seeks intertextuality between them and extra-textual or discursive references. Such an interpretation is based both on the analysis of tourist industry discourses and on the contributions of postcolonial theories about the representation of the non-occidental Other, especially on Edward Said's core writings. His main idea is that the Orient, as a reified, timeless world, as an absolute Other for the Occident, which is characterized by recurrent time and space, has been created through the discourses of Westerners. An interdiscursive approach enables him to identify and define, within two hundred years of world history, what he considers to be a discourse, in the Foucauldian meant it, of the Orient, of its existence, its characteristics and its inhabitants. According to Said, such a discourse is part of the western process of colonisation in so far as the "West", that is to say its scientists, politicians and writers, has invented an Other and considered it as an object in order to dominate and subdue it. While Said's work has often been criticized - he is mainly accused of having himself invented, reified and homogenized an East according to his own view of orientalism -, it is quite obvious that there are traces of the orientalist discourse, for example in today's popular culture in France, and that their reality, though multiple and heterogeneous, cannot be denied. $\underline{3}$

The object of this paper is not to discuss the discrepancy between the reality and its representation since they are by nature incommensurable, but the collation of representations and images of China which are contradictory, even opposed, within the tourist industry, by juxtaposing a traditional orientalist representation on the one hand, with the increasingly obvious Chinese modernity on the other hand. This modernity is mainly embodied by the traces of modern history which are put forward as historical objects by the tourist industry. Yet, references to a Chinese modernity do not necessarily contradict the backward-looking orientalist discourse in so far as modernity is nowadays conjugated in the past and is no longer synonymous with that which is contemporary. How do the travel agents negociate the bend? How do they manage to include the signs of modernity within a classic orientalist discourse, based on the presentation of China as mythical and reified, symbolised by a timeless and radically different culture ? By referring recurrently to a China in the present, ambitious and active, do they not deconstruct the orientalist imaginary of a non-historic China, as they describe it ? This question is here developed around the analysis of a corpus

\footnotetext{
Japanese popular culture for an "Asia" which has not lost its oriental identity. "Asia" represents here Japan's past and is meant to reveal what this country has already lost, see "Nostalgia for a (Different) Asian Modernity: Media Consumption of 'Asia' in Japan", Positions: East Asia Cultures Critique, Vol 10, n³ , 2002, pp. 547-573, 3 Said has notably been reproached with playing into the hands of the fundamentalisms of the Middle-East. In China, since the first translations of his writings (in the early 1990's), the anti-imperialist dimension of his arguments and his criticism of the occidental cultural hegemony are sometimes used by nationalist discourses, see Yingjie Guo, Cultural Nationalism in Contemporary China: The Search for National Identity under Reform, London, Routledge Curzon, 2004, pp. 109-132. The purism of nationalist ideologies and of their exclusive logics is however to Said's thinking since he kept writing that identity is an intellectual construction, always hybrid and constantly evolving. In an interview published in Interventions: International Journal of Postcolonial studies, Volume 1, Number 1, 1998, pp. 81-96, Said goes back over the takeover of his theories by fundamentalist movements: "and to think that in some way my book licenses these characters [fundamentalists] (sic) to fulminate against something called the west, which is a position I abjure. I say even the notions of the Occident and Orient are ideological fictions and we should try to get away from them as much as possible." In this article, the words Orient and Occident represent "ideological fictions". 4 Franck Michel, Désirs d'Ailleurs : Essai d'anthropologie des voyages, Strasbourg, Editions Histoire \& Anthropologie,
} 
of "tourist texts" of two different periods: the years 1996-1998 and the years 2003-2005. Despite the fact that these moments are chronologically close, there is a gap between the types of discourse due to the, apparent, suddenness of the changes and modernisation in China in recent years, even if the imaginary which is evoked does not directly refer to a reality. Rapid modernisation coupled with swift economic development have been constant in China over the last twenty years whereas its representation, in French media and popular culture, as a hypermodern capitalist country, undergoing dazzling, even worrying, changes, is a very recent phenomenon.

The 1996-1998 brochures refer to the classic imaginary of China as an orientalised, timeless and past-oriented country, as the 0ther, both mysterious and mystical. They offer but few historical elements concerning modern China while their references and discourses about contemporary urban China are restricted to the specific case of Hong Kong and, even more sporadically, to the nascent modernity in the cities of Beijing and Shanghai. As opposed to that in the 2003-2005 texts, modern and contemporary China is more obviously taken into account, but without renouncing the orientalist imaginary of an unchanging and exotic destination.

\section{Timeless and Other}

The discourse inscribing China as a timeless country, protected from history and modernity, is a permanent feature in the tourist industry. The places and monuments which the travel agents offer their clients belong to "traditional" and imperial China ; therefore the illustrations almost always represent elements from the past. The tourist industry is always in search of differences, whether they be cultural, spatial or temporal, hence its systematic use of the symbolism of the past, whatever the country. ${ }^{4}$ Nevertheless, in comparison with the discursive treatment of other countries, especially with that of European countries, the Chinese, "oriental", specificity is conveyed through the particular status of the past in relation to the present: the tourist industry does not produce a "folklore" past, or a "museum" past, which would have already undergone a process of preservation as a heritage, but tends rather to assert that the past is present in China, that it is actually living. ${ }^{5}$ Just as Bernard d'Abrigeon claims solemnly in the introduction of a "tourist documentary" that "[En Chine] le présent s'enracine dans le passé" ([In China] the present is rooted in the past), a travel agent reveals, concerning Asia, that "chaque geste suppose le secret de civilisations millénaires" (each gesture implies the secret of age-old civilisations), while another highlights "I'habileté asiatique naturelle et des techniques millénaires pour un shopping différent" (the natural Asian skill and age-old technics that produces a different kind of shopping). $\underline{6}$ The "age-old

2002, p. 180, 5 On the distinction between the heritage and a work of art in a museum, Rachid Amirou reminds us that the heritage "est sous la menace du temps et des hommes, on parle alors de 'protection'; ; 'œuvre exposée au musée est censée traverser, immuable et inchangée, les époques et les péripéties humaines, on la 'conserve'" (is threatened by time and men, it is then a matter of "protection"; the work exposed in a museum is supposed to go, immutable and unchanged, through the times and the human events, it is 'preserved'"), Imaginaire du tourisme culturel, Paris, PUF, 2000, p. 77. 6 Bernard d'Abrigeon, La Chine du Sud: des trains pas comme les autres, France, Vidéo Editions Montparnasse/France 2, 1993 ; Asietours 1999, Accortour, p. 1 Toute l'Asie 2002-2003, Asia, p. 4. 
civilisations" are not embodied here by objets d'art or historical monuments which would be regarded as relics from the past, hence to be "protected" or "preserved", but they are conveyed through practices, they lie within "each gesture", they live and come through "Asian" bodies. The essentialisation of corporal practices is also found in the assessment of an "Asian skill" which is said not to come of history but of nature, without refering to a specific place or people but rather to Asia as an entirety, as if there were a biological "Asian identity". Such statements, since they generalize and reify, are typical of the orientalist discourse. The tourist industry keeps trying to give evidence of the contemporaneousness of the past by stressing the traditional aspects of the Chinese's everyday lives through daily practices which are said to be "immuable", immutable or unchanging, in synchrony with the vestiges of the past which the tourist is about to visit. An emphasis is laid on the practices, the skills, the customs and the whole of the "patrimoine immatériel" (immaterial heritage), "patrimoine vivant" (living heritage), or even "mentefacts" in order to distinguish them from the tangible heritage the artefacts consisting of monuments and objects from the past. Rachid Amirou differenciates the immaterial heritage which refers to "formes mortes (vestiges) [...] qu'on retrouve dans le résultat des collectes conservées dans les archives de folklore ou dans les musées d'ethnologie" (dead forms (vestiges) [...] to be found in the results of collections which are preserved in folklore archives and ethnology museums) from the supposedly living heritage which defines "I'ensemble des traditions ou pratiques ludiques [actuelles] inscrites dans la vie quotidienne d'une communauté" (the whole of the [current] traditions or ludic activities inscribed in the everyday life of a community). ${ }^{?}$ UNESCO now recognizes some "immaterial" culture as part of the world heritage of humanity. In this regard, it sets itself the task of preserving some daily cultural practices as it does for architectural monuments. When insisting on the living heritage, the travel agents for their part postulate that practices from the past are "permanent" because such practices are said to be naturally part of the daily contemporary lives of the Chinese. Besides, in accordance with the view which most often prevails in the French media and cultural sphere, the tourist industry discourse thrusts forward the idea that post-maoist China has been recovering its past over the past few years:

Entre Tai-Chi et Chi-Kong, gymnastiques traditionnelles qui se pratiquent dans la rue, et les pratiques de mah-jong, réhabilitées après Mao, les Chinois renouent avec leur passé, emplissent de nouveau les temples, vénèrent l'esprit des ancêtres puis passent comme si de rien n'était au modernisme le plus avancé. .8

Between Tai-Chi and Chi-Kong, traditional gymnastics practised in the streets, and the practices of mah-jong, brought back after Mao, the Chinese take up their past again, fill the temples again, venerate the ancestors' spirits then shift as though nothing had happened to the most advanced modernism

Together with the idea of a rebirth of the past, of a wakening of China, goes the orientalist discourse stressing its stasis and the timelessness as inscribed in the travel agents use and abuse of adjectives such as "unchanging", "eternal" or "timeless" to qualify China. Adding to this double emphasis, the brochure illustrations represent mostly elderly people, symbols of the past and of the status quo.

A world of the past, China is also a world of the elsewhere. The second type of prevailent and

7 Amirou, Imaginaire du tourisme culturel, p. 23. 8 Asietours 1999, Accortour, p. 60, 9 Asie : voyages sur mesure, mars/octobre 2005, Kuoni, p. 43, 10 Kuoni, 1998-2000, p. 106. 
dominant classic discourse in tourist brochures is that of otherness and strangeness. Here again, China is confused with a supposedly homogeneous "Orient" and becomes the Other, radically different from an occidental "us". The tourist industry essentializes this otherness and difference which is characterized by the recurring dichotomies Orient-0ccident. Thus, as soon as modernity is mentioned a form of cultural hybridity is at stake ; Hong Kong, a "savoureux mélange d'Orient et d'Occident" (tasty mix of Orient and Occident). ${ }^{9}$ The travel agents insist on the idea that China, and the Orient too of course, is "un autre monde" (another world), where the laws of nature are not always applied, where mysterious and irrational forces prevail, and where strange things actually happen. The discourse of radical alterity focuses particularly on the spiritual and religious forces which are supposed to be omnipresent there. The brochures therefore recount "les mystères du yin et du yang" (the mysteries of the yin and yang), "des chemins initiatiques" (initiatory paths), "divinités et de sages" (deities and sages). They describe "des pèlerins (qui) se frottent à un chiffon imprégné d'encre pour s'approprier les vertus des textes sacrés qu'on imprime depuis le Moyen-Âge" (pilgrims who rub themselves with a cloth impregnated with ink so as to take over the powers of sacred texts which have been printed since the Middle Ages). 10 Asia is said to be "terre de spiritualité" (a land of spirituality). This Chinese-Asian-Oriental spirituality is implicitely located in opposition to a materialistic Occident:

\begin{abstract}
En Asie, le bien-être est pratiqué au quotidien. Médecine chinoise, herboristerie aux pharmacopées aussi efficaces qu'insolites à nos esprits cartésiens, acupuncture précise et presque magique, aromathérapie dont les huiles visent au rééquilibrage du corps et de l'esprit, en Asie, la chimie occidentale n'est guère de mise. 11

In Asia, well-being is a daily practice. Chinese or herbal medicine using pharmacopoeia which are as efficacious as they are strange to our Cartesian minds, precise and almost magical acupuncture, aromatherapy with oils aimed at re-etablishing the balance of body and mind, in Asia, Western chemistry is quite out of place.
\end{abstract}

In this way, by opposing "almost magical" techniques to Western practices, "Oriental" skills are located in a realm which has nothing to do with reason, suggesting the Asian's lack of rationality.

\title{
Dreaming in the intertexts of the past
}

Gilbert Trigano, founding father of the well-known travel agency Le Club Méditerranée, gives the tour operators the name "vendeurs de rêve" (dealers in dream). The manager of an Australian agency, quoted by the sociologist Rachid Amirou, similarly asserts:

Ne parlez pas de l'idée de ce que vous rêvez de lui vendre ; partez de l'idée du rêve qu'il veut acheter et vous taillerez votre marchandise sur ce modèle. 12

Do not start from the idea of what you dream of selling him; start from the idea of the dream that he wants to buy, and you make your product suit the idea. 
Therefore the tourist industrialists sell China as it is dreamt by the potential tourist, that is to say that what they apply themselves to representing in their brochures is not a Chinese reality but China as it exists in the popular imaginary. Rachid Amirou, who states that a tourist is always seeking what he names un "inconnu connu" (a known unknown), explains that "tout voyage s'apparente ainsi à une tautologie, on va 'découvrir' ce qu'on connaît déjà" (any trip amounts to a tautology, we want to 'discover' what we already know). 13

Since the exoticism that the tourists look for is always marked out, the tourist industry discourse does not refer to the Chinese reality but China in the imaginary of French tourists. ${ }^{14}$ When the publicists assert that China is "un monde intemporel" (an world out of time) and Asia the kingdom of the irrational, or even that the Chinese people are "a people of gamblers", they are certainly not referring to China as a reality or even to its history. Roland Barthes uses the word "sinité" to evoke this "thing" which is not China:

La Chine est une chose, l'idée que pouvait s'en faire, il n'y a pas longtemps encore, un petitbourgeois français en est une autre : pour ce mélange spécial de clochettes, de pousse-pousses et de fumeries d'opium, pas d'autre mot possible que celui de sinité. 15

China is a thing, the idea that a French petit-bourgeois could get, even a short time ago, is another thing: for this special mix of small bells, rickshaws and opium dens, no other word is possible than that of sinité (sinity).

The representations of China reflect the past of the society and of the country in which they are expressed, that is to say here the history of the representations of China and of the Chinese in France and in Europe. As Edward Said explains the concept of representation: "We must be prepared to accept the fact that a representation is eo ipso implicated, intertwined, embedded, interwoven with a great many other things besides the 'truth' which is itself a representation." He adds that representations are to be considered as "inhabiting a common field of playing defined for them, not by some inherent common subject matter alone, but by some common history, tradition, universe of discourse." 16 The Chinese as a gamester is a stereotype which we often come across in tourist brochures. ${ }^{17}$ It calls up his recurring representation as a "congenital gambler" in racist discourses in Europe at the end of the XIX ${ }^{\text {th }}$ century as Gregory Lee analyses in his works on the history of anti-Chinese racisms. ${ }^{18}$ The referent of the representation is external to what it is supposed to represent, that is "truth" or reality, and the image is fed, enriched, and most of all justified and legitimated in the mirror of other images. The tourist industry discourse integrates this circular movement and the brochures sometimes openly call up this "universe of discourse" as in the following example about Shanghai in which the "aventures de Tintin \& Milou" (The adventures of Tintin \& Milou)

\footnotetext{
13 Amirou, Imaginaires touristiques et sociabilités du voyage, p. 94 ; Amirou, in the same work, quotes Francis Affergan: "La figure de l'autre, déjà construite avant le voyage, ne constitue ni une surprise, ni un événement puisqu'elle a pour fonction épistémique d'épouser intimement le modèle" (the other's figure, already built before the trip, is neither a surprise, nor an event since its epistemic function is to embrace intimately the model), p.94. Franck Michel also considers that "[le voyage est] vérificateur d'histoire passée plus facilement que producteur d'histoire immédiate" (A trip is more easily a verification of a past history than a producer of an immediate history), Désirs d'Ailleurs : Essai d'anthropologie des voyages, p. 98. 14 The "French" are not referred to as a people here, but as social and cultural categories which are defined and targeted by the marketing professionals of the tourist industry. 15 Roland Barthes, Mythologies, Paris, Editions du Seuil, 1957, p. 194, 16 Said, Orientalism, p. 305, 17 It is written for example that the Chinese "prend la vie comme un jeu" (takes life as a game), Toute l'Asie en voyage individuel sur mesure, 2004-2005, Asia, p. 163, 18 Gregory B. Lee, Chinas Unlimited: Making the Imaginaries of China and Chineseness, London, Routledge Curzon; Honolulu, University of Hawai'i Press, 2003, p. 32.
} 
and the "romans de science fiction des années 40 et 50" (1940s' and 1950s' science fiction novels) are referred to as elements of comparison with the Chinese reality:

Etonnant ensemble de bâtiments de style 1920-1930 et de grande majesté, construits le long d'une magnifique corniche qui longe les quais de cette ville dont le nom résonne à nos oreilles comme des aventures de Tintin \& Milou. En face de cette ville et de l'autre côté du fleuve Huang $\mathrm{Pu}$, la nouvelle ville de Pudong avec ses gratte-ciel qui ressemblent étrangement aux couvertures des romans de science fiction des année 40 et 50.19

Surprising block of majestic buildings in the 1920-1930 style built along a magnificient coast road which runs alongside the embankments of this city, the name of which rings like the adventures of Tintin \& Milou in our ears. Opposite this city and on the other side of the river Huang Pu, the new city of Pudong with its skyscrapers which look amazingly like the covers of forties and fifties science fiction novels.

Significantly enough, Tintin \& Milou do not refer to the city of Shanghai itself here, but to its name, an element of the "universe of discourse" which "rings... in our ears".

The non-"Cartesian" Oriental and its past-oriented civilisation recur in discourses which, as Said showed in his writings, have invented their own object: the Orient. The "known unknown" sought by tourists in China or in Asia corresponds to an orientalist imaginary which, though it is positive when produced by the tourist industry now, was part of a very negative and critical discourse at the end of the XIX ${ }^{\text {th }}$ century: to the China having preserved its traditions in spite of modernity which the tour operators present, echoed a China unable to change as the travellers and colonial administrators, as well as the writers and philosophers, described it. The Count of Beauvoir, relating his trip in China in Voyage autour du monde, wrote in 1868 : "Cette civilisation s'est figée depuis longtemps" (This civilisation fixed a long time ago). ${ }^{20}$ The Baron Charles de Chassiron, who stayed in China at the end of the 1850's and was a member of the French embassy when the Treaty of Tianjin was signed in 1858, claimed: "La Chine est le pays de l'immobilité" (China is the land of inertia). ${ }_{21}^{2}$ The tourist and globe-trotter Louis Carpeaux commented as a conclusion of the book he issued in 1913: "L'âme de la Chine, c'est la tradition, l'éternelle tradition" (The soul of China is tradition, the eternal tradition). 22 This congenital inertia is to be found at the same time in the following statement by Ernest Renan who tries to demonstrate theoretically the supposed Chinese stagnation:

La Chine est en quelque sorte une Europe non perfectible : elle a été dès son enfance ce qu'elle devait être à jamais, et telle est la raison de son infériorité. $\underline{23}$

China is in a way an inachievable Europe: it was, since its infancy, what it was to be forever, and that is the reason for its inferiority.

In the years 1950, Fernand Gigon, a swiss journalist who wrote many books on Asia, introduced his work Asie Multiple (Multiple Asia) with an amazing remark:

19 Rev'Asie, Hiver 2004-2005, Groupe Teker, p. 8. 20 Beauvoir, (Comte) De, Voyage autour du monde, Paris, Plon, 1968, p. 611, 21 Charles (Baron) De Chassiron, Notes sur le Japon, La Chine et I'Inde, Paris, Dentu et Reinwald, 1861, p. X. 22 Louis Carpeaux, Pékin qui s'en va, Paris, Maloine, 1913. 23 Tristan D'Huriel (établie par), La Chine vue par les écrivains franç̧ais, Paris, Bartillat, 2004, p. 98. This idea of China as a non-evolutional civilisation, mature from its birth, is present two centuries earlier in Voltaire's writings, see Jonathan D. Spence, La Chine imaginaire : Les Chinois vus par les Occidentaux de Marco Polo à nos jours, Montréal, Les Presses de I'Université de Montréal, 2000, p. 113. 
Le monde peut évoluer, passer de la Joconde de Léonard de Vinci au E=MC2 d'Einstein, sans que l'Asie bouge d'un millimètre ou que son apport au progrès, à notre progrès occidental, varie en qualité et en quantité. De toutes les civilisations, celles de l'Asie sont peut-être les seules à être immortelles. Leur immobilité leur assure une protection contre l'usure du temps et du mouvement. Elles vivent en fonction de l'éternité. 24

The world can evolve, pass from Leonardo da Vinci's Mona Lisa to Einstein's E=MC2 without Asia moving one inch or without its contribution to progress, to our Western progress, varying in quality and quantity. Of all civilisations, the Asian civilisations may be the only immortal ones. Their inertia protects them from being worn away by time and movement. They are living according to eternity.

Indeed the vision of China as a world out of time corresponds to a wider discourse relative to the "Orient" in general. It is obviously not by chance that the depiction of Asia as inert emerged during the period of XIX $X^{\text {th }}$ colonial expansion, especially French and British. The "Orient" as an object, passive and stagnant, was to be transformed, developed and, finally, civilised by the hands of those who had defined it. As the travel anthropologist Franck Michel explains: "hier comme aujourd'hui, parler de la Chine immobile a toujours sous-entendu l'idée sournoise de pouvoir la rendre mobile à notre gré !" (yesterday as it does today, talking about neverchanging China has always implied the pernicious idea of making it movable as we pleased)..$\underline{25}$ The representation of timelessness has gone through the ages and is now summoned up again and made positive in a contemporary discourse of the Other, be it the "Oriental" or Chinese other. The historicity of these images and discourses is also present when the tourist brochures exalt a mysterious and exotic land of the "Orient", imbued with mysticism, magic and spirituality. These images echo, in the past, through the prism of Christian missionnaries on the one hand and of the rationalist philosophy of the Enlightenment on the other hand, the critical visions of lands where "superstition" prevails, of stagnant peoples who are left behind by History because they are unable to reason. $\underline{26}$

The discourse of the inertia of Chinese civilisation and the spiritual and intellectual deviances, or inadequacies, of the Chinese go hand in hand with the colonial period of the XIX ${ }^{\text {th }}$ century. These representations do not exist apart from the situation of economic and military supremacy of the occidental powers in China and from its consequences in the cultural and religious realms. China was only semi-colonised but it found itself in an inferior position from the middle of the XIX ${ }^{\text {th }}$ century and its image in France and in Europe was greatly affected by it, as Muriel Détrie explains in her work on travel stories in China: "A partir de la fin du XIXe siècle, on constate en effet dans les récits de voyage une dégradation accélérée de l'image de la Chine" (From the end of the XIX ${ }^{\text {th }}$ century onwards, a fast degradation of the image of China is indeed noticeable). 27

This image of the "China-as-0ther", as far as we can go back in history, has always been conditioned and oriented by the ideological agenda of those who produced it, their discourse being standardized according to the political, cultural and epistemological conditions of their

\footnotetext{
24 Fernand Gigon, Multiple Asie, Paris, Editions Arthaud, 1958, p. 9, 25 Franck Michel, En route pour l'Asie : le rêve oriental chez les colonisateurs, les aventuriers et les touristes occidentaux. Strasbourg, Editions Histoire \& Anthropologie, 1995, p. 73, 26 For example, Paul Claudel wrote in Sous le signe du dragon (1948) a terrible comment on the supposed characteristics of the Chinese "spirit": "Le Chinois se développe plus lentement, sent plus lentement, pense, apprend et agit plus lentement que l'Européen" (The Chinese develops more slowly, feels more slowly, thinks, learns and acts more slowly than the European), quoted in Ninette Boothroyd, Muriel Détrie, Le voyage en Chine : Anthologie des voyageurs occidentaux du moyen âge à la chute de l'empire romain, Paris, Seuil, 1992, p. 749. 27 Boothroyd, Détrie, Le voyage en Chine, p. 511.
} 
time. For instance China was a land of an alternative revolutionary credo in the 1960s for a part of the youth and of the intelligentsia of Western Europe when the last illusions on the situation in the Soviet Union were falling appart. In the same way, when Voltaire praised the Chinese political institutions and moral standards in the middle of the XVIII century, his main purpose was to oppose the clergy in France and to put forward as an example a model of society and of state power which, though without any christian foundations, was sophisticated, organised and efficient. Finally, did not Marco Polo, who is said to have written the first detailed travel story on China, through a minute representation of their chastity and virtue profer Chinese women an example for his own daughters ? $\underline{28}$

Although the discourse employed by the tour operators corresponds precisely to widespread a priori and prejudices common at the end of the XIX ${ }^{\text {th }}$ century, it adapted to the new "needs" of the Western orientalist imaginary. While, in the XIX ${ }^{\text {th }}$ century, the colonial powers exposed the decline of the non-0ccident and denounced its lack of rationality in order to provide a rationale for its strategy of colonization, the tourist industry now offers exotic oriental remedies to assuage the crisis of modernity in Western societies. The copy writer of the brochures on Asia, produced by a French travel agency, indeed presents Asia as the kingdom of self-care and of individual well-being against a Western world which he describes as stressful: "Le bien-être est tendance. Valeur montante dans un monde incertain et anxiogène que génère notre $21^{1}$ siècle" (Well-being is in the air. A value on he rise in the uncertain and anxiety-ridden world which our $21^{\text {st }}$ century brings about). ${ }^{29}$

\section{The "endless present" of the post-modern Orient}

In the tourist industry discourse, China is nowadays not only considered as an exotic refuge located in age-old times. Géographical distance does no longer systematically mean temporal distance. In the representations they give of China, more and more elements of the modern Chinese history are now integrated into the tourist brochures. This Chinese modernity can be found in the usual clichés of the colonial atmosphere of the concessions as offered by a tour operator who plans a stop at The Face, a bar in Shanghai:

Ambiance exotique, dans une maison coloniale au milieu d'un parc, avec lits à opium et touche décadente, bar aux parfums des années 20. 30

Exotic atmosphere, in a colonial-style house in the middle of a park, with opium beds and a touch of decadence, a bar with a whiff of the twenties.

Modern China is also represented through the very recent past of the People's Republic. Even the possibility of visiting a "Mao-retro" Beijing is on offer:

28 Spence, La Chine imaginaire, p. 31. 29 Plages d'Asie : séjours et bien-être en Asie, 2004-2005, Asia, p. 2. 30 Toute l'Asie en voyage individuel sur mesure, 2004-2005, Asia, p. 175 
A la rencontre d'une mouvance rétro-chic très actuelle à Pékin : visite de l'ancienne résidence de Mei Lanfang, chanteur adulé de l'opéra de Pékin, puis de la maison de Song Qingling, hérö̈ne communiste, avec son mobilier année 50 et ses photos de l'époque maoïste. 11

Meeting a retro-smart trend which is in now in Beijing: visit to the former residence of Mei Lanfang, a much adulated singer of the Beijing Opera, followed by the visit of a communist heroin, Song Qingling's house, with its 50s furniture and its photos of the Mao period.

This imaginary representation of the postimperial period seems to fit almost naturally, as in a painting, into a reifying exotic and orientalist discourse. Mentions of Mao, opium dens or the Cultural Revolution are so many signifiers of a recent, modern past, the historic dimension of which has been rubbed out, and which are as if spread out on the surface of the present on an anachronistic table, placed alongside with other symbolical objects such as the Forbidden City, the Great Wall, the Ming Tombs, Beijing's back alleys, or even the ethnic minority peoples. These elements, as if displayed in the window of a souvenir shop, are put beyond History so as to be in the service of the consumer-tourist. ${ }^{32}$ One of the main features of tourism is that it deprives of any historical dimension the places and monuments it puts on sale. China in the $X^{\text {th }}$ century is already a "place of memory", a vestige from the past, therefore the tourist industry discourse on modern China must not be considered "cured" of orientalist ideology. Chinese modernity, whether it be the capitalist and liberal variety of 1930s Shanghai or the Maoist and revolutionary of the 1960s, remains exotic and timeless. Thus while Edward Said wrote that to "write about the modern Orient is [...] to reveal an upsetting demystification of images culled from texts", almost thirty years later we find that even the modern itself is mystified. ${ }^{33}$ When Said writes of the "modern Orient", he means an Orient which would be contemporary with those who represent it. The "upsetting demystification" can only become effective if the "East attains a relation of temporal simultaneousness with the West. It is then no longer an unchanging world, located in the past, as always described in texts. Nevertheless, even more than a contemporary Orient, what Said names the modern Orient is also synonym with the real Orient, that a romantic like Gérard de Nerval would never have wished to visit so as not to "Iose" its imaginary vision of the Orient: "For a person who has never seen the Orient, Nerval once said to Gautier, a lotus is still a lotus; for me it is only a kind of onion". ${ }^{34}$ Representing China as "modern" does not entail a demystification since the opium bed, the cultural revolution or the figure of Mao are actually nothing but images collected in texts, as are the bent roofs of traditional houses, the Great Wall or, as part of the living immaterial patrimony, the Chinese as a gamester. "Modern China" is already in a position of diachrony with the present time. ${ }^{35}$ Can writing on a "postmodern Orient" today, in so far as it would be contemporary with the "Occident", be considered to "reveal an upsetting

\footnotetext{
$31 \mathrm{lbid}, \mathrm{p} .171$. The tourism section of a special issue on China of the famous French magazine Paris-Match mentions a restaurant in Beijing, the "Pekin Sunflower Village Food Street", where you can order dishes which have been invented by Chinese peasants to overcome starvation during the Cultural Revolution, Février- Mars 2003, p. 112. 32 Gilles Lipovetsky, Les temps hypermodernes, Paris, Grasset, 2004, p. 127. 33 Said, Orientalism, p.120. 34 Ibid, p. 120. 35 Paul Ricoeur, in his book La mémoire, I'histoire, I'oubli, Seuil, 2000, discusses the idea of modernity (pp. 400-413). He focuses on the personal pronoun "our" which often comes in the expression "our modernity" and notices that "our" is used to distinguish a modernity of today from other times in the past which were already called modern. He quotes Vincent Descombes who, in his article "Une question de chronologie" (A matter of chronology) in Jacques Poulain, Penser au présent, Paris, L'Harmattan, 1998, pp. 43-79, clearly identifies the idea of modernity with the past among contemporary philosophers: "En d'autres temps, des mots aussi chargés que ceux de 'temps présent', 'monde moderne', 'modernité' auraient évoqué des phénomènes d'innovations et de rupture [...] depuis une vingtaine d'années, ces mêmes thèmes du moderne et du présent sont pour les philosophes
} 
demystification of images culled from texts, "the word "postmodern" being here synonymous with a contemporary modernity different from the "previous modernities", thoses of the past? ${ }^{36}$ It first seems that the tourist industry discourse contributes to a process of demystification of the orientalist imaginary since it mentions quite recurrently not only Chinese modernity as an object of the past (China of the time of the concessions, Maoist China), but China's present too. The fact that the tourism professionals care to highlight contemporary China has to be seen in the context of an economic and political strenghening of this country. In the discourse of the media and in the prevailing popular imaginary, China is nowadays not only the eternal and ancestral the Middle Kingdom but the economic, political, hence cultural, power of toworrow too. The image of China changes as the relations of economic domination and the geopolitical hegemonies are challenged: the passiveness of oriental wisdom turns progressively into the worrying aggressiveness of Chinese and Asian capitalism. ${ }^{37}$ History becoming Chinese and the idea that Asia will be hegemonic one day is gaining ground. 38 China now calls up the present and even sometimes the future: "Un nouveau monde en marche qu'il est facile de voir dans les galeries et les quartiers futuristes de Shanghai" (A new world in progress observable in the galleries and futuristic quarters of Shanghai). ${ }^{39}$ In the same way, the statement "Vivez le XXI e siècle avec Shanghai et Hong Kong" (Live through the XX|lst century with Shanghai and Hong Kong) gives substance to the idea that China might have entered historical time, that it might have a future, the XX|st century, therefore that it might have had a past too, losing its timelessness in the meantime. 40

Might not this new "reality" of Chinese contemporaneousness, as conjured by the dream dealers of the tourist industry, induce a head-on clash of imaginaries ? If tourists dream of a "known unknown", a China born in the texts of the past, then what is the dialectical way to represent contemporary China's future-oriented living, unexpected and in synchrony with the world in which the tourists themselves without devastating the oriental fantasies and myths

une occasion de se tourner vers leur passé. Ce qui est désigné comme moderne semble être derrière nous." (In other times, words bearing strong meanings such as "present time", "modern world", or "modernity" would have described phenomena of innovation or break-up [...] for the last twenty years, the same themes of the modern and the present are used by philosophers to turn to the past. What is called modern today seems to be behind us.), La mémoire, I'histoire, l'oubli, p. 406. For the dealers of imaginary which the tourist industry professionals are, the word "modern" as applied to China can also represent a time of the past. Yet the equivalence modern = past is not systematic in their discourse since the expression "modern China" is sometimes synonimous with "today's China" 36 See Ricoeur's idea of competition between the two uses of the word "modernity": a "repetitive concept" used by the "history of representations" and a concept, synonymous with "our time" which distinguishes "our modernity" from "previous modernities", La mémoire, I'histoire, l'oubli, p. 409, 37 This representation of China as a potential threat became more concrete when in Spring 2005 the controversy about the importations of Chinese textiles broke in the media. The fact that the disclosure of the so called economic "invasion" was sudden and massive (most of the big national dailies dealt with the subject on their front page) was surprising considering that the directives from the WT0 exempting China from taxes on such exports as of March, $1^{\text {st }} 2005$ on had been common knowledge for several years. 38 it is in this regard worth quoting the mention of an Asia-power which is getting ready to attack in the song "Europe" by Noir Désir, a highly politicized French rock band: "Euromonnaie unique, Nasdaq et CAC 40, orgiaque, idyllique, faites de la poésie, soutenez la culture, produisez du spectacle et de l'entertainment comme on dit chez nos frères d'Outre-Atlantique et toc anciens Européens, nouveaux maîtres du monde pendant que le dragon asiatique rêve, fait ses étirements, il est beau et puissant, crache du feu gentiment" (One Euromoney, Nasdaq and CAC 40, Orgiastic, idyllic, do poetry, support culture, produce shows and entertainment as our brothers from across the Atlantic, former Europeans and new world masters, say, while the Asian dragon is dreaming, training, it's beautiful and powerful, kindly belching out fire); a new column (since early 2005), exclusively on China, of the satirical weekly Charlie-Hebdo is entitled: "Des nouvelles de notre futur" (News from our future), 39 "Toute l'Asie en voyage individuel sur mesure, 2004-2005», Asia, p. 163, 40 «Tentation d'Asie, hiver 2002-2003», Asia, p. 54. 
of an exotic and unchanging China of the past?

The solution to this equation is to be found in the way the tourist industry insists on lending a postmodern dimension to China by granting this polemical and critical notion a triple signification. From a purely chronological point of view, postmodern China would come after a modern China which would have become an object of history and entered museums. An ideological dimension is generated with the idea of a postmodernity interpreted as a modernity having brought its project to a conclusion, a "successful" modernity, reconciled with its past, in full harmony with the previous culture as if, in China, the social and cultural contradictions of modernisation had been overcome, as if History had come to its end. This postmodern condition finally assumes a culturalist signification since, instead of being the result of a historical process, the end of a linear history, it would be nothing but the natural condition of Orient, a world in a "perpetual present" where non-linear time would have neither past nor future. Rather than the idea of an achieved modernity implying a process of evolution, it is therefore the idea of a Chinese (or Oriental) postmodernity which is foregrounded when travel agents mention contemporary practices, especially those of urban China. Shanghai is, in this regard, described as follows:

Poussée par une jeunesse créative et ambitieuse, Shanghai affiche fièrement sa vitalité ravageuse. Nouvelle économie, musique techno, galeries avant-gardistes sont les moteurs d'une population enthousiaste, qui ne renie rien de ses racines et sait se ressourcer dans des jardins zen immuables. 41

Driven by a creative and ambitious youth, Shanghai proudly exhibits its devastating energy. New economy, techno music, avant-gardist galleries are the mainsprings of an enthusiastic population, who disown nothing of their roots and know how to refresh themselves in immutable Zen gardens.

Besides the fact that Zen is a Japanese word for a branch of buddhism in Japan, historically inspired by the Chinese Chan buddhism, the expression "immutable Zen gardens" corresponds rather to the Zen fashion current nowadays in Shanghai which paradoxically comes from the so-called Oriental spirituality "products" that you can find in the West. If hypermodernity is represented by "New economy, techno music, avant-gardist galleries" and local "roots" by the "Zen", it has after all nothing to do with the harmonious fusion of tradition and modernity as the tourist industry marketing suggests. The "realities" which are all the products of the economic and cultural globalisation belong to one world: the Zen fashion in Shanghai is not less modern or more Oriental than avant-gardist galleries.

The tourist industry aims at showing that in China avant-gardism and modernism are trends which induce no break with the past. The union of economic avant-garde and tradition can be read also in comments about Beijing:

Nous sommes dans les hutongs, entrelacs d'allées et de maisons familiales qui faillirent bien disparaître dans les grands travaux urbanistes de Pékin, mais qui sont aujourd'hui heureusement sauvés et réhabilités par les jeunes cadres branchés de la capitale désireux de retrouver un peu de leurs racines dans un cadre traditionnel modernisé. 42

41 Toute l'Asie en voyage individuel sur mesure, 2004-2005, Asia, p. 164. 42 Tentations : Toute l'Asie en circuits, été 2005, Asia, p. 72. 
We are in hutongs, a network of alleys and family houses which almost disappeared in the big town-planning works of Beijing, but which have been fortunately saved now and restored by the young and switched-on executives of the capital who are anxious to recover some of their roots in a modernised traditional framework.

How can a "framework" be both "traditional" and "modernised" unless it is assumed that in China the processes of modernisation, or just simply time going by, cannot transform the elements of the past, in this case, the tradition. The juxtaposition of the "avant-garde" or the "young and switched-on executives" with "immutable Zen gardens" and the desire for "roots" tends to prove that finally, if China and the Orient have a history, if they are inscribed in the contemporary, this contemporary cannot be severed from the past. One of the main features of Oriental temporality is that it is in this regard a past which does not pass. In China, as read in a brochure, "tradition et modernité font bon ménage" (tradition and modernity get on well with each other) and "créativité visionnaire et respect des anciens oeuvrent en synergie" (visionary creativity and respect for the elders strive in synergy). $\stackrel{43}{3}$

As Pierre-André Taguieff recalls in his work L'effacement de l'avenir, modernity was mainly criticised by Western thinkers, and first of all by Nietzsche, for its "presentism", for creating a world "dénué du sens de la tradition, coupé donc du passé, et privé d'avenir" (devoid of a sense of tradition, cut off the past and deprived of a future). ${ }^{44} \mathrm{He}$ adds that the postmodern condition is nothing but "la modernité arrivée au moment où elle se comprend elle-même" (modernity having reached the moment it can understand itself). ${ }^{45}$ Time with neither past nor future is "the temporally-amputated experience of the moderns, and this [negative] experience is henceforth a conscious reality for most of our contemporaries" (l'expérience temporelle amputée des modernes, et cette expérience [négative] est désormais présente à la conscience de la plupart de nos contemporains ). $\stackrel{46}{4}$ The negative crisis of time proper to modernity as described by Tagueiff echoes the positive discourse on time and history in the so-called "Orient". The postmodern (non)historical condition, the essence itself of the Orient in the tourist industry discourse, is indeed seen today as a quality and an advantage in a world in which the past would no longer give sense to the present and in which the future would be unknown and uncertain. The supposed absence of anxiety towards the future and towards death is therefore actualized and most of all naturalized by the dream-makers: "Le soi-disant fatalisme oriental n'est peut-être que la vraie sagesse de peuples sachant vivre pleinement l'instant présent" (So-called Oriental fatalism may be nothing but the true wisdom of peoples who know how to live fully the present moment). 47 This statement clearly shows the shift from the traditional image of "Oriental fatalism" to the very postmodern idea of "liv[ing] fully in the present moment" without disturbing the present moment with either the past and its weights or the future and its expectations. The following quotation forcefully puts forward the discourse which naturalizes what is supposedly innately Chinese philosophy of "instantaneousness":

Avec peut-être en dénominateur commun, une faculté, fascinante pour les visiteurs, de ces Chinois de toutes origines à prendre la vie comme un jeu, à rire, à parier, à tenter les dieux pour voir, à demander l'impossible pour l'oublier dans l'instant, et à rire à nouveau. 48

43 Though one of the main features of the orientalist discourse is the objectivization of the Other, China becomes here a subject when "the young and switched-on executives", "a creative and ambitious youth", or "the avant-garde" are mentionned. 44 Pierre-André Taguieff, L'effacement de l'avenir, Paris, Galilée, 2000, p. 98. 45 |bid, p. 102.46 Ibid, p. 99 ; For a political approach of the question of time, see Jean Chesneaux, Habiter le temps, Paris, Bayard, 1996. 47 Fêtez-le en Asie, 1999-2000, Asia, p. 3. 48 Toute l'Asie en voyage individuel sur mesure, 2004-2005, 
With maybe as a common denominator the ability, so fascinating for visitors, of Chinese of all backgrounds to take life as a game, to laugh, to gamble, to tempt the gods just to see, to ask the impossible and forget it straight away, and laugh again.

Located on a very thin line of the present, the Chinese, "of all origins", are hence said to have the in-born capacity to "ask for the impossible and forget it straight away". "Betting", "tempting the gods", "ask for the impossible" are all attitudes which require a quality which the Chinese are said to have in common: recklessness. Devoid of any temporal perspective, the Chinese would be unaware of the consequences of their actions. The structure of the above-cited sentence is itself cyclical and therefore calls up the idea of a time which goes round in circles and always goes back to its starting point. When the tourist industry claims that the Chinese have an innate capacity to "live fully in the present moment", it has indeed a positive effect on its sales in a world which does not have a historical sense anymore. But, neither is this a new cliché, but rather a variant of the myth of historical stasis. Arthur H. Smith, reknowned for its description of Chinese "characteristics" at the end of the XIX analysis of the Chinese, to demonstrate the Chinese lack of a notion of historicity:

Mais ce temps futurn'existe pas dans la langue chinoise, pas plus du reste qu'aucun autre temps du verbe. Le Chinois dit simplement : " Fais travail, reçois argent », ces deux derniers mots étant l'idée principale qui demeure dans son esprit : le « rapport du temps » n'existe pas pour lui ! 49 But this future tense does not exist in the Chinese language, not more by the way than any other tense. The Chinese simply says: "Do work, receive money", the last two words being the main idea which remains in his mind: the "time connection" does not exist for him !"

China offered a political model to Western societies which challenged in the past this orientalist vision. But this is no longer so, the "meta-narratives" based on an evolutionary and often determinist vision of History, are now outmoded. The tourist industry discourse presents China like a natural model of pacific postmodernity, hence suggesting that the Orient has always been postmodern. $\underline{50}$ Its aim is to go beyond the critical and negative image of a Western modernity at odds with its past by suggesting an oriental postmodernity which would be characterized both by its entrenchment in the past and in the traditions and by a paradoxal form of presentism echoing the discourse of oriental timelessness. Timelessness is here located in the contemporaneousness. ${ }^{51} \mathrm{~A}$ tourist telling the story of her trip, as quoted in a brochure, mixes contemporary present and imutable time too. She wants "at the same time" to visit out of time places and to find herself in "today's China", "its present life", "modern times":

\footnotetext{
49 Smith, Mceurs curieuses des Chinois, p. 54, 50 The idea of a postmodern Orient present in the academic circles as Gregory Lee recalls in his criticism of the book l'Instant éternel by the sociologist Michel Maffesoli. The latter, a postmodern orientalist, echoes the tourist industry discourse as he states that: " les 'Orients mythiques' prennent leur revanche et imposent, par l'accentuation du présent, une présence au monde, à ses plaisirs, à ses joies, mais aussi à ses cruautés et à ses peines. ", cité dans Gregory B. Lee, La Chine et le spectre de l'Occident : Contestation poétique, modernité et métissage, Paris, Syllepse, 2002, p. 28, 51 As in the following note: "La Chine historique, celle éternelle, toujours présente et peut-être même de plus en plus vivante, dans des temples-pagodes sauvés des années rouges et repeints de carmin frais, et aujourd'hui très fréquentés par des citadins affairés qui n'hésitent pas à demander l'aide du ciel avant d'entamer une négociation difficile." (The historical China, the eternal one, always present and maybe even more and more alive, in pagoda-temples saved from the Red years and repainted with fresh crimson, and nowadays much frequented by busy city dwellers who do not hesitate to ask for heaven's help before entering into a difficult negociation), Toute l'Asie en voyage individuel sur mesure, 2004-2005, Asia, p. 163.
} 
Je suis d'avance convaincue d'acheter des remèdes mystérieux dans des herboristeries intemporelles, et en même temps, je suis décidée à laisser faire, à respirer l'air des temps modernes et à toucher du doigt la Chine d'aujourd'hui, à connaître sa vie actuelle, son déjà cinquième millénaire. $\underline{52}$

I am already convinced that I will buy mysterious remedies in timeless herbalist's shops, and at the same time, I'm determined to let myself go, to smell the air of modern times and to catch a glimpse of today's China, to know its present life, its already fifth millenary.

The tourist industry discourse therefore maintains the illusion that in the Orient an alternative modernity unalienated from the past can be found. The copy writer for the agency's brochure goes deeper into this idea as he dreams of an "orientalisation" of the world. According to his "disclosures", Asia's staff would have "fait le rêve, égoïste, d'une grande planète aux couleurs de l'Asie, qui serait à la source d'une mondialisation des sagesses et un facteur d'unification civilisée" (made a dream, an egotistical dream, of a large planet bearing the colours of Asia, which would be the source of a globalisation of wisdoms and a vector for civilised unification). ${ }^{53}$ In the opinion of this propagandist of the Orientalist cause, this dream is getting more real every day considering the growing influence of so-called Oriental practices in Westerners' everyday life: philosophies, spiritualities, practices of well-being, architecture, cooking and so on. He adds that:

L'idée fait son chemin : l'art de vivre, aujourd'hui, se décline oriental. Tendances vestimentaires, gastronomie épicée, design épuré, architecture zen, sérénité spirituelle, le catalogue des envies s'est largement ouvert en Occident, et le fengshui, reiki, sushi et autres origami ont envahi nos vies. $\underline{54}$ The idea is gaining ground: the art of living, nowadays, is orientalized. Clothing trends, spicy cuisine, refined design, Zen architecture, spiritual serenity, the catalogue of desires has been much enlarged in the West, and fengshui, reiki, sushi, origami and all have invaded our lives.

The "catalogue of desires" mentioned hereabove lists the goods producted by a capitalism which, as the philosopher Maurizio Lazzarato has it, is no longer characterized by its "mode de production" (mode of production) but by the " production de mo(n)des" (production of modes/ fashioned worlds). $\frac{55}{5}$ The marketing and business communication professionals, when creating new products, invent the worlds (ways of living, desires, beliefs, values) which correspond to them and "compel" the consumers to conform to them. The Orientalist discourse is nowadays no longer confined to literature, it has infiltrated marketing agencies, advanced posts of the contemporary capitalism which reproduces it in a variety of forms and media. Though the real Orient does not exist, it has been a discourse and an image for centuries. It is this recuperated image, adapted to a targeted population and reinvented by the market, which, as the editorialist of Asia notes, is now Orientalized in the global market. The "Orient", in the tourist industry discourse, no longer represents a career opportunity, as Disraeli wrote two centuries ago, but a "wonderland", a modern world which has been exempted from the alienations of Western modernity: lack of sense and spirituality, uprooting, loss of harmony with nature, of cultural identity, rupture from the past and tradition, excessive materialism and so on. In the dream dealers' discourse, going East today no longer equates with a trip back in time, but an opportunity to visit the wonderful world of the "endless present."

52 Toute l'Asie en voyage individuel sur mesure, 2004-2005, Asia, p. 163. 53 Tentations D'Asia, hiver 2002-2003, Asia, p. 2. 54 Plages d'Asie : séjours et bien-être en Asie, 2004-2005, Asia, p. 1, 55 Maurizio Lazzarato, Les révolutions du capitalisme, Les empêcheurs de penser en rond, Paris, 2004, p. 96. 